\title{
Malignant mixed tumor
}

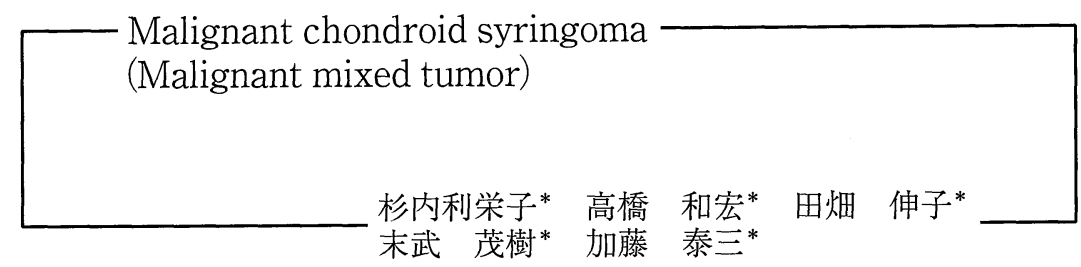

\section{Summary}

We report a case of malignant chondroid syringoma affecting the preauricular portion of the left ear of a 67-year-old man. There were submental lymph node metastasis and multiple pulmonary metastases two months later. The local recurrence occurred at the primary site about 12 months after the initial insufficient surgical procedure. We suspected clinically squamous cell carcinoma was suspected. However, the findings of the histopathological, immunohistochemical and ultrastructual examinations for reccurent tumor led us finally to make a diagnosis of malignant chondroid syringoma. Patient received electron beam radiation followed by administration of chemotherapeutic agents including CDDP, 5 -FU and irinotecan and taxotere. We discussed the usefulness of such combination therapy, particulary the chemotherapeutic agents including taxotere.

Key words : Malignant chondroid syringoma, Mixed cell tumor, Radiation, Chemotherapy, Taxotere

\section{はじめに}

Chondroid syringoma は, 汗腺由来の附属器 腫瘍として位置づけられている1”。その大部分 は良性であるが，稀に進行性で転移を起こす。 このような aggressive chondroid syringoma な いしは metastasizing chondroid syringoma と呼 ばれるタイプのものは, 現在では malignant chondroid syringoma な し は malignant mixed tumor (of the skin) として間質変化を持 つ汗腺系悪性腫瘍に分類されている。 Malignant chondroid syringoma は, 比較的稀な

* Rieko SUGIUCHI, Kazuhiro TAKAHASHI, Nobuko TABATA, Takaki SUETAKE, Taizo KATO: 東北大 学皮膚科学教室
疾患であり, 1961 年の Hirsch ら 2) の報告以来, 本邦報告例 4 例を含み，33 例に過ぎない ${ }^{3)}$ 。臨 床的には, 男女比 $1: 2.3$ と女性に多く, 平均年 齢は 57 歳 ( 13 歳から 83 歳), 四肢・体幹を好 発部位とする腫瘍である ${ }^{344}$ 。我々は, squamous cell carcinoma との鑑別に苦慮した malignant chondroid syringoma の 1 例を経験し たので，報告する。

\section{症例}

患 者：63 歳，男性

初 診: 1995年 9 月 29 日

家族歴：特記すべきことはない。

生活歴：13 歳の時, 広島の爆心地近くにおい て被爆した。 
現病歴: 32 歳時, 左耳前部に腫瘤が出現し, 一度切除を受けている。62 歳になり同部に再度 小豆大の結節が出現し，その後急速に拡大して きた。10月前より下顎部にリンパ節を触知する ようになり受診した。

現 症: 左耳前部に約 $11 \times 10 \mathrm{~cm}$, 高さ $5 \mathrm{~cm}$ の表面凹凸不整の紅色から黄褐色の有菱性の腫 瘤がある (図 1 )。左眼閉眼障害, 表情筋麻痺な どの顔面神経麻痺症状を伴う。

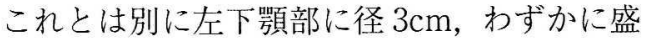
り上がりのある腫瘤を触れる。

臨床検查所見: 末梢血, 生化学検査などの一 般検查において異常は認められなかった。血清 SCC 抗原も正常範囲であり, 胸部 X 線において も肺転移を思わせる所見はなかった。

MRI 所見：左耳前部から煩部にかけてキノコ 状に突出する巨大な腫瘤が認められる(図 2)。 左耳下腺に执いては脂肪構造が消失し, 腫瘍の 浸潤が示唆された。

治療および経過：初診時, 臨床的に有棘細胞 癌を考え，生検を施行した。増殖する未分化な 腫瘍細胞塊の中に一部角化傾向が認められたこ とより, 組織学的にも有棘細胞癌と診断した。 手術を前提として, 連日 CDDP $7 \mathrm{mg} /$ body の点 滴と電子線照射 (2Gy/日) を開始, 併せて週 2 回 10KEのピシバニール局注を施行した。しか

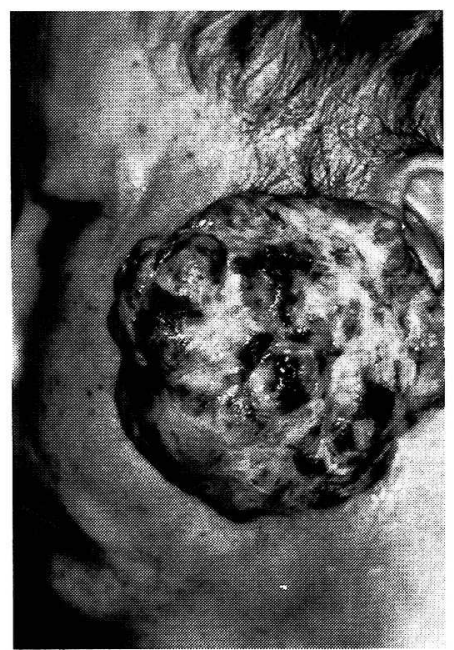

図 1，左耳前部の腫崵
し，2 カ月経過した時点で，肺に多発性転移が 出現した。腫瘍からの出血を止め, 腫瘍量を減 らすことを目的として外頚動脈を結紮後に腫瘍 を辺縁で切除した。腫瘍は，耳下腺付近におい て脂肪組織が腫瘍細胞に置き変わり浸潤してい た。術後電子線を局所にさらに50Gy, 総量 94Gy 照射するとともに, CDDP，5-FU，イリノ テカンによる化学療法を施行した。初診 1 年を 経過した時点で, やや増大傾向のある下顎部リ ンパ節を，さらにその 2 カ月後原発部に再発し た径 $1 \mathrm{~cm}$ の結節（図 3）を切除した。現在夕キ ソテールにて化学療法を施行している（表 1)。 肺の多発性の転移巣は, 大きさ, 数ともに変動 はみられず，原発巣にも再発を思わせる所見は ない。左耳の閉塞感, 咳を伴う軽度の血痰を認 めるが，全身状態は，比較的良好である。

病理組織学的所見：姑息的に切除した標本 は, 全体が壊死性変化で占められ, 腫瘍細胞の 性状を知る手がかりは得ることができなかっ た。図 3 に示した再発病巣の切片では, 真皮に 表皮との連続性にそしい腫瘍塊が認められ基底 細胞様細胞が管腔構造 (矢印) を呈しながら増 殖している (図 4)。腫瘍細胞は, 核 / 細胞質比 の大きい好塩基性に染まる比較的小型の細胞で ありこれれが索状ないし網目状に配列してお り(図 5 ), 一部で管腔様・嚢腫様構造（図 6, 7) をとっている。これらの腫瘍細胞は PAS 陽性, d-PAS 陰性であり,グリコーゲンを豊富 に含んでいる。管腔様構造の部分では間質がア

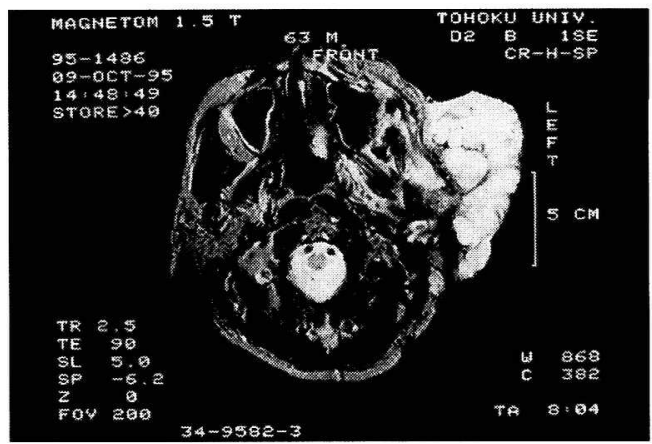

図 2.MRI所見 耳下腺付近まで腫瘍が浸潤している 


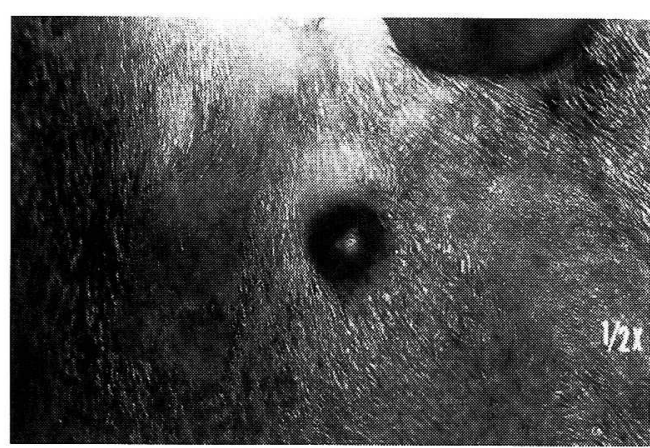

図 3．原発部に生じた結節

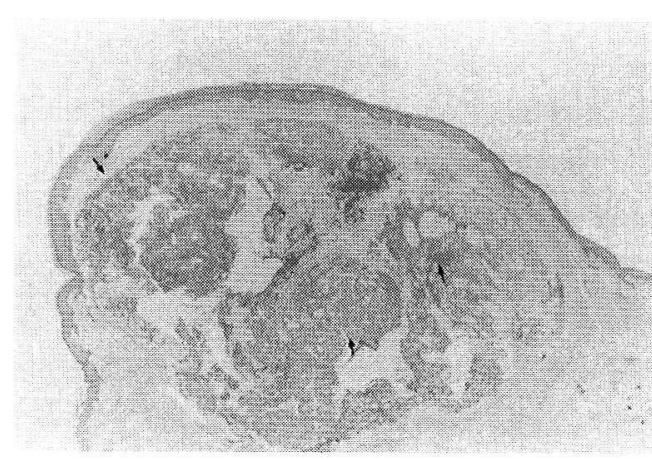

図 4. 弱拡大 $($ H. E. $\times 4)$

基底細胞様細胞が管腔様・賈腫様構造（矢印） を呈しながら增殖している

表 1 . 治療と経過

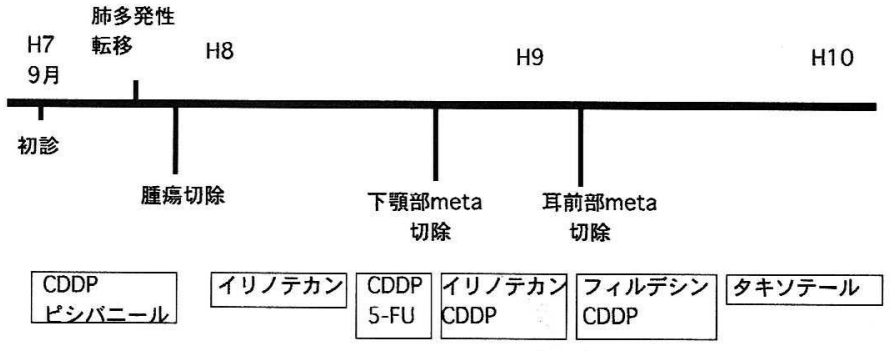

電子線総量94Gy

(耳前部)

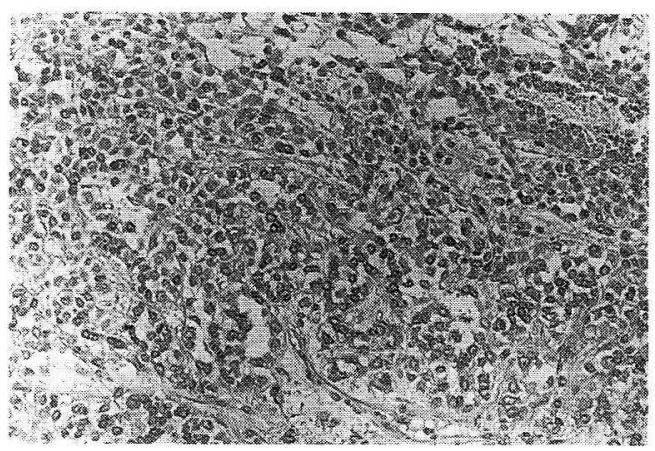

図 5.腫瘍細胞が索状ないし網目状に配列して增殖 している部分 (H.E. × 40)

ルシアンブルー陽性, トルイジンブルーに異染 性を示し, ムチン沈着が示唆された（図８）。下 顎部リンパ節転移部においては, 原発巣類似の 小型の腫瘍細胞が密に浸潤していた。

免疫組織学的所見：腫瘍細胞は CEA および chromoglanin 陰性を示した。cytokeratinに対 しては, 陽性を示す細胞と陰性の細胞がほぼ半

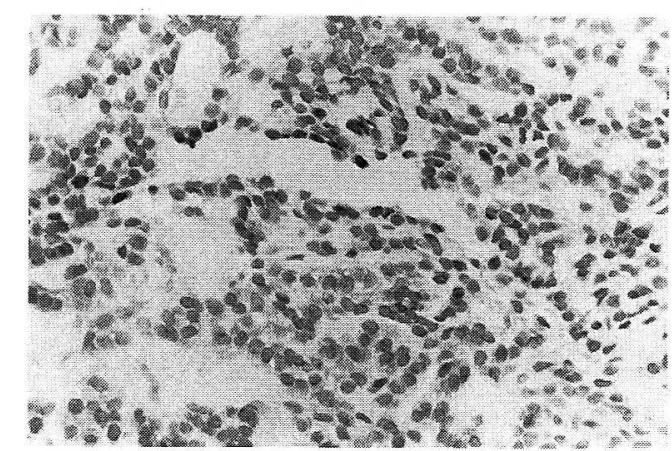

図 6. 管腔様構造を示す部分 (H. E. × 40)

分ずつの割合でみられ，陽性細胞は S-100 蛋白 も陽性であるのに対して，陰性細胞は vimentin に陽性であった。

電顕所見：腫瘍細胞の胞体には, トノフィラ メント，メラノソームが存在し，基底膜との間 にはへミデスモゾームが発達しており，隣接す る細胞との間にデスモゾームの形成がみられた 


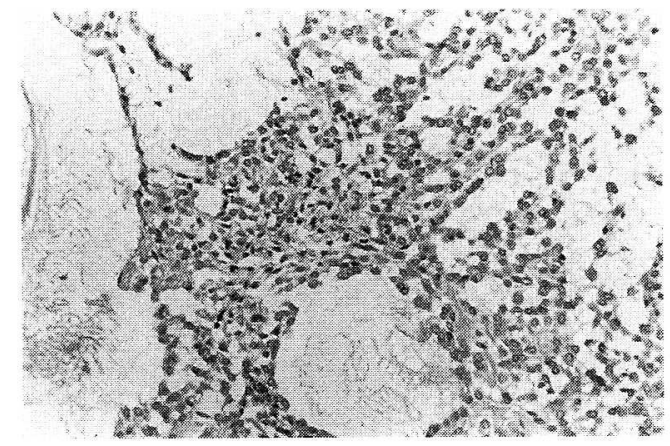

図 7.囊腫様構造を示す部分（H. E. × 40）

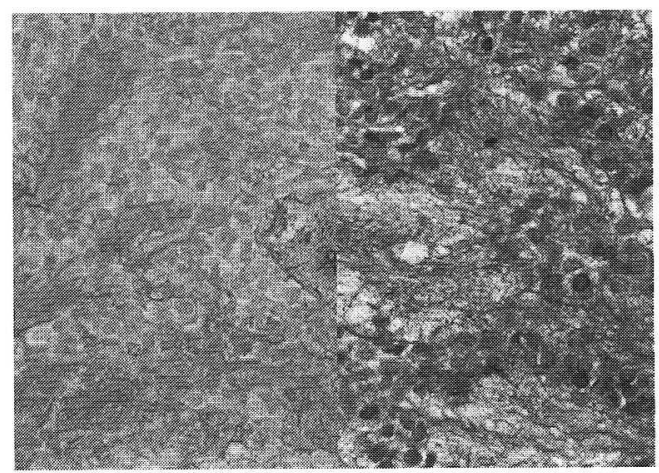

図 8.管腔様構造の部分ならびに腫瘍細胞の間質に はアルシアンブルー陽性（左）トルイジンブ ルーに異染性を示すムチンが沈着していた( 右) (H. E. $\times 40)$
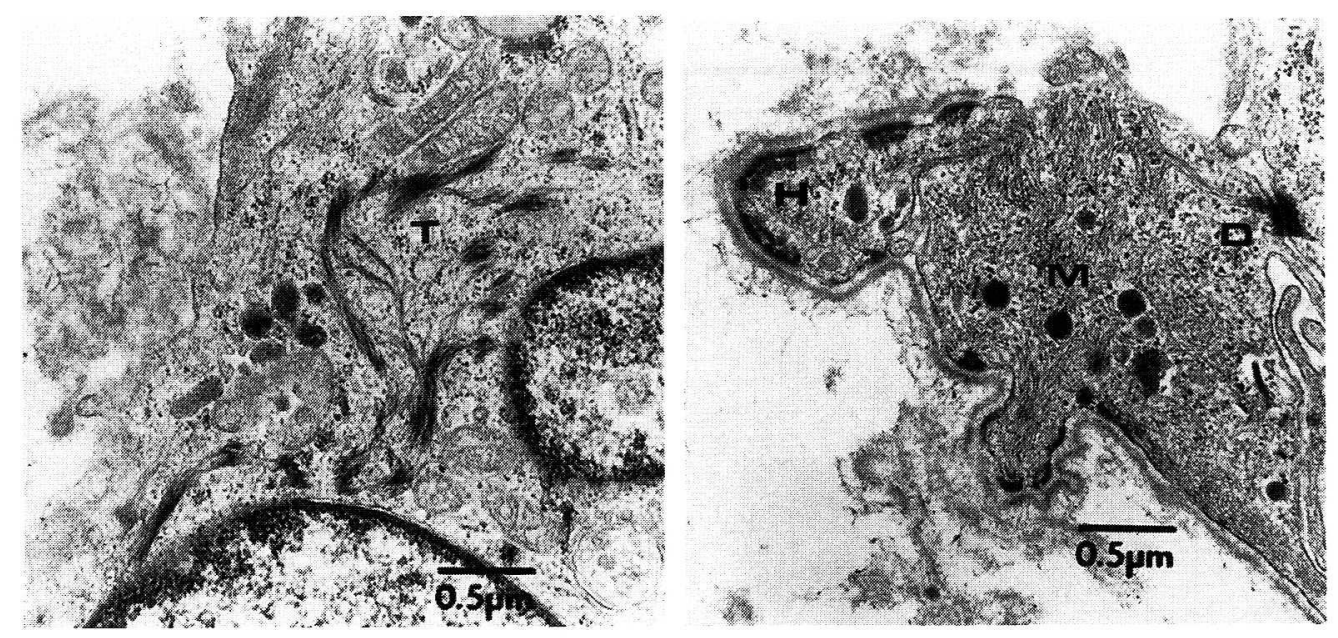

図 9.腫瘍細胞の胞体には，トノフィラメント $(\mathrm{T})$ ，メラノソーム（M）が存在している. 基底膜との 間にはへミデスモゾーム $(\mathrm{H})$ が発達し，脌接する細胞との間にデスモゾーム (D) を形成してい る $(\times 3600)$

(図 9)。これらの所見は有棘細胞癌および malignant chondroid syringoma のいづれも否 定するものではない。

\section{考察}

有棘細胞癌との鑑別に苦慮した malignant chondroid syringoma の 1 例を報告した。生検 標本において一部に角化傾向のみられたことか ら当初は有棘細胞癌と診断した。姑息的な手術 組織の大部分が壊死組織であり，全体の構築が 十分に把握できなかったことも確定診断をつけ
にくくした要因であると思われる。しかし，腫 瘍細胞が一部管腔構造をとること, keratin, vimentin および S-100 蛋白など免疫組織学的に 多様性を示したこと，さらに間質のムチン沈着 が確認されたことから，最終的に malignant chondroid syringoma と診断した。Malignant chondroid syringomaは, 局所再発,リンパ節転 移，遠隔転移を起こしやすい，極めて悪性度の 高い腫瘍であると考えられる ${ }^{3)}$ 。自験例に扔い ても, 局所再発, リンパ節転移, 多発する肺転 移がみられ，当初その予後には悲観的であっ た。しかし，局所再発もなく，また肺転移は消 
失しないまでも大きさ，数とも変動なく推移 し, 初診後 3 年を経過した現在も悪性腫瘍と共 存する形で生存している。本症における治療指 針は，症例数が少ないこともあり，いまだ確立 されていないが, 自験例の場合は一連の集学的 治療が有用であったものと思われる。この中 で, 化学療法剈としては, CDDP, 5-FU, イリ ノテカン, フィルデシン, およびタキソテー ル 5) を組み合わせて使用した。現在は，外来受 診時にタキソテールのみの投与を行っている。 今後も注意深く経過をみていきたい。

謝 辞：御校閲頂きました，東北大学皮膚科学教 室教授田上八朗先生に深謝致します。

\section{文献}

1）斎田俊明，他：いわゆる皮虐混合腫瘍. 皮虐病診 療, $6: 829,1984$.

2）横山明子, 他：悪性皮膚混合腫瘍の一例. Skin cancer, $12: 61-66,1997$.

3 ) Hirsch, P., et al. : Chondroid syringoma : mixed tumor of the skin, salivary gland type. Arch. Dermatol., $1961 ; 84$ : 835-47.

4) James, C.Steinmetz, et al. : Malignant chondroid syringoma with wide spread metastasis. J. Am. Acad. Drematol., 22:845-847, 1990.

5）塚越茂: 新抗癌剤, Docetaxel（タキソテール）に ついて. 癌と化学療法, 24(9): 1167-1174, 1997. 